\title{
Citrus Tristeza Virus Isolates of the Same Genotype Differ in Stem Pitting Severity in Grapefruit
}

\author{
Glynnis Cook, ${ }^{1,2, \dagger}$ Beatrix Coetzee, ${ }^{2}$ Rachelle Bester, ${ }^{2}$ Johannes H. J. Breytenbach, ${ }^{1}$ Chanel Steyn, ${ }^{1}$ Rochelle de Bruyn, ${ }^{1}$ \\ Johan T. Burger, ${ }^{2}$ and Hans J. Maree ${ }^{2,3}$ \\ ${ }^{1}$ Citrus Research International, Nelspruit, 1200, South Africa \\ ${ }^{2}$ Department of Genetics, Stellenbosch University, Matieland, 7602, South Africa \\ ${ }^{3}$ Citrus Research International, Matieland, 7602, South Africa
}

\begin{abstract}
Two isolates of the T68 genotype of citrus tristeza virus (CTV) were derived from a common source, GFMS12, by single aphid transmission. These isolates, named GFMS12-8 and GFMS12-1.3, induced stem pitting with differing severity in 'Duncan' grapefruit (Citrus $\times$ paradisi [Macfad.]). Full-genome sequencing of these isolates showed only minor nucleotide sequence differences totaling 45 polymorphisms. Numerous nucleotide

derived from the same source, but showing differences in pathogenicity. The results demonstrate the development of intragenotype heterogeneity known to occur with single-stranded RNA viruses. Identification of genetic variability between isolates showing different pathogenicity will enable interrogation of specific genome regions for potential stem pitting determinants.
\end{abstract} changes, in relatively close proximity, were detected in the $\mathrm{p} 33$ open reading frame (ORF) and the leader protease domains of ORF1a. This is the first report of full-genome characterization of CTV isolates of a single genotype,
Keywords: viruses and viroids, pathogen diversity, CTV genetic variants, symptom diversity, closterovirus
Citrus tristeza virus belongs to the genus Closterovirus in the family Closteroviridae (Martelli et al. 2012) and has a single-stranded, positive-sense RNA genome of approximately $19.3 \mathrm{~kb}$ (Karasev et al. 1995). The virus is phloem restricted and transmitted in nature by various aphid species in a semipersistent manner (Bar-Joseph et al. 1989; Sasaki et al. 1980). Genome sequencing has shown a high sequence divergence with eight phylogenetic clades or genotypes (Harper 2013; Yokomi et al. 2018). This genetic diversity is, however, poorly linked to symptom expression in the host.

Citrus tristeza virus (CTV) is the cause of widespread destruction of citrus propagated on the sour orange $(C . \times$ aurantium $\mathrm{L}$.) rootstock by quick decline or "tristeza" disease (Moreno et al. 2008). Stem pitting of citrus is also caused by CTV. Severe, destructive stem pitting was reported on grapefruit and sweet orange but also on other citrus types such as acid limes (Broadbent et al. 1992; Hughes and Lister 1949; Müller et al. 1968). Stem pitting is observed as distinctive pits or grooves in the wood, below the bark. Tree decline associated with stem pitting resembles that of tristeza, but the decline is more gradual and seldom results in the death of the tree; rather, affected trees often yield small and unmarketable fruit (van Vuuren and da Graca 2000).

Due to widespread, severe stem pitting in sweet orange, grapefruit, and lime, mild-strain cross-protection was investigated in a number of countries and implemented in Australia, Argentina, Brazil, Peru, and South Africa as a disease management strategy (da Graca and van Vuuren 2010). The mild sources currently used for cross-

${ }^{\dagger}$ Corresponding author: G. Cook; glynnis@cri.co.za

GenBank accessions: MK033510 and MK033511.

Funding: The authors thank the Citrus Growers' Association of Southern Africa/Citrus Research International for the funding of CRI project 1100.

*The $\boldsymbol{e}$-Xtra logo stands for "electronic extra" and indicates that three supplementary tables are published online.

The author(s) declare no conflict of interest.

Accepted for publication 20 March 2020.

(C) 2020 The American Phytopathological Society protection were empirically selected and evaluated. Sources were obtained from symptomless trees, found in severely affected orchards or by passaging sources through various hosts, followed by glasshouse and field testing (Muller and Costa 1987; Roistacher et al. 1987, 1988; van Vuuren et al. 1991). The selection process is lengthy, and only a few candidate sources have been identified (Muller 1980; Roistacher and Dodds 1993).

CTV was a limiting factor in the production of grapefruit in South Africa due to severe stem pitting, which reduced the average lifespan of white grapefruit cultivars to 15 years and red cultivars to 10 years (Marais 1994). Mild-strain cross-protection was introduced as a means to retain the commercial viability of grapefruit in South Africa (da Graca and van Vuuren 2010). A CTV source was obtained from a white grapefruit tree (unknown cultivar) on the farm "Nartia" in the Western Cape Province of South Africa in 1972, and all citrus budwood, initially supplied through the South African Citrus Improvement Scheme, was preimmunized with this Nartia mild source, later referred to as GFMS12 (Marais 1994). Subsequently, GFMS12 was replaced as a source for grapefruit cross-protection when severe stem pitting, ascribed to a probable segregation event, was observed with this source (van Vuuren and Manicom 2005).

Single aphid transmissions from the original GFMS12 source plant generated nine isolates that were biologically characterized. These isolates were found to differ in stem pitting severity, although genetic differences could not be established by either restriction fragment length polymorphism or single-strand conformation polymorphism patterns of the coat protein gene (van Vuuren et al. 2000).

This study reports biological and genetic characterization of mild and severe stem pitting isolates of the T68 genotype derived from the same source, GFMS12. We report minor nucleotide changes between mild and severe stem pitting isolates. The highest density of nucleotide changes was mainly detected in the p33 open reading frame (ORF) and the leader protease (LPro) domains of ORF1a. These differences are important leads to investigate possible stem pitting determinants.

\section{Materials and Methods}

GFMS12 sources. The original GFMS12 source, also referred to as the Nartia source, was obtained in 1972 and established on a Volkameriana rootstock (Citrus $\times$ limon cv. Volkameriana [L.] Osbeck) and is still maintained at the Agricultural Research Council - Tropical and Subtropical Crops (ARC-TSC) in Nelspruit, Mpumalanga, in an 
insect-proof tunnel. A propagation source was established in 2004 on Duncan grapefruit and maintained in a glasshouse at Citrus Research International (CRI), Nelspruit. This propagation source developed severe stem pitting (Fig. 1).

Isolation of GFMS12-8 and GFMS12-1.3. Single aphid transmissions from the original GFMS12 source plant were previously performed to obtain isolates in 1996 (van Vuuren et al. 2000). The source was first inoculated to Mexican lime (Citrus $\times$ aurantifolia [Christm.] Swingle), which was used as the acquisition host and from there single aphids were transferred to Mexican lime receptor plants. Nine isolates of GFMS12 were obtained and biologically characterized. A selection of these isolates, including GFMS12-8, are maintained in Mexican lime at CRI, Nelspruit.

A bark patch of the Duncan grapefruit GFMS12 source plant, showing severe stem pitting, was grafted to a Mexican lime seedling for aphid transmission. Approximately 20 to 30 nonviruliferous aphids, Toxoptera citricida (Kirk.), were transferred to the acquisition host and allowed an acquisition feeding period of $24 \mathrm{~h}$. Thereafter, four to five aphids were placed on a single Mexican lime seedling for an inoculation access period of $24 \mathrm{~h}$, and aphids were physically removed thereafter. Receptor plants were tested for CTV transmission after 1 month with a generic CTV reverse transcription polymerase chain reaction (RT-PCR) assay (Cook et al. 2016). Single aphid transmissions were performed in 2016 from one of these positive plants, and a positive plant from the second transmission was maintained as isolate GFMS12-1.3 in an insect-proof glasshouse.

Genotype determination of propagation sources of GFMS12 and isolates. The CTV genotype composition of the original GFMS12 source plant was determined by CTV genotype-specific RT-PCR, as previously described, which specifically targets differential regions in ORF1a for genotypes T36, T30, VT, T68, T3, HA16-5, and two RB variant groups (Cook et al. 2016). Six samples were taken at different positions of the tree, and bark of green twigs was used to extract RNA. The Duncan grapefruit GFMS12 propagation plant and isolates GFMS12-1.3 and GFMS12-8, maintained at CRI, were also tested using the same genotype-specific assays.

Biological evaluation of GFMS12-1.3 and GFMS12-8. The two isolates, GFMS12-8 and GFMS12-1.3, derived at different times from different propagation plants of the GFMS12 source, were comparatively tested on the "Garnsey" host range (Garnsey et al. 1987). The isolates were inoculated to the citrus hosts with four to six replicates for each host, dependent on availability. Inoculations were performed by grafting bark pieces from the respective Mexican lime source plants to each scion. Side branches were removed, and a single shoot was allowed to grow from the top bud of each plant. Plants were maintained in an aphid-free glasshouse with average day temperatures ranging between 24 and $28^{\circ} \mathrm{C}$ and average night temperatures between 12 and $20^{\circ} \mathrm{C}$. Midday temperatures exceeded $35^{\circ} \mathrm{C}$ at times. Each inoculated plant was tested for successful transmission by RT-PCR using the generic CTV assay. Symptom expression was recorded at 6 months. Stem pitting was observed by steaming the cut stems in an autoclave for $10 \mathrm{~min}$ prior to bark removal. The individual component scores for symptoms on each Garnsey host were averaged and the composite score multiplied by the weight factor for each host. The final disease index was obtained by adding the scores for each citrus host (Garnsey et al. 1987).

Two further sets of Duncan seedlings were inoculated for validation and evaluated for stem pitting. The first set included four replicate trees per isolate, which were cut back 4 months postinoculation and again after a further 12-month growth period. The second set included five repetitions per isolate, which were cut back 9 months postinoculation.

Full-genome sequence determination of isolates GFMS12-8 and GFMS12-1.3. Full-genome sequences for isolates GFMS12-8 and GFMS12-1.3 were obtained by RT-PCR amplification of overlapping genome segments of approximately 1,500 bp and direct Sanger sequencing. RNA was extracted from the Mexican lime hosts for sequencing, as previously reported (Cook et al. 2016). One microgram of total RNA was denatured at $65^{\circ} \mathrm{C}$ for 3 min with $0.2 \mu \mathrm{g}$ of Random Hexamer Primer (Thermo Scientific, Waltham, MA) and placed on ice for $1 \mathrm{~min}$. Further reaction components were added to the denatured RNA, including reaction buffer, dNTPs $(1 \mathrm{mM}$ final concentration), $100 \mathrm{U}$ of RevertAid H Minus Reverse Transcriptase (Thermo Scientific), and $10 \mathrm{U}$ of RiboLock RNase Inhibitor (Thermo Scientific) in a final reaction volume of $20 \mu$ l. Reverse transcription was performed at $25^{\circ} \mathrm{C}$ for $5 \mathrm{~min}$ followed by $42^{\circ} \mathrm{C}$ for $60 \mathrm{~min}$ in a Multigene Optimax thermal cycler (Labnet International, Edison $\mathrm{NJ})$. Samples were heated for $10 \mathrm{~min}$ at $70^{\circ} \mathrm{C}$ to terminate the reverse transcription reaction.

A

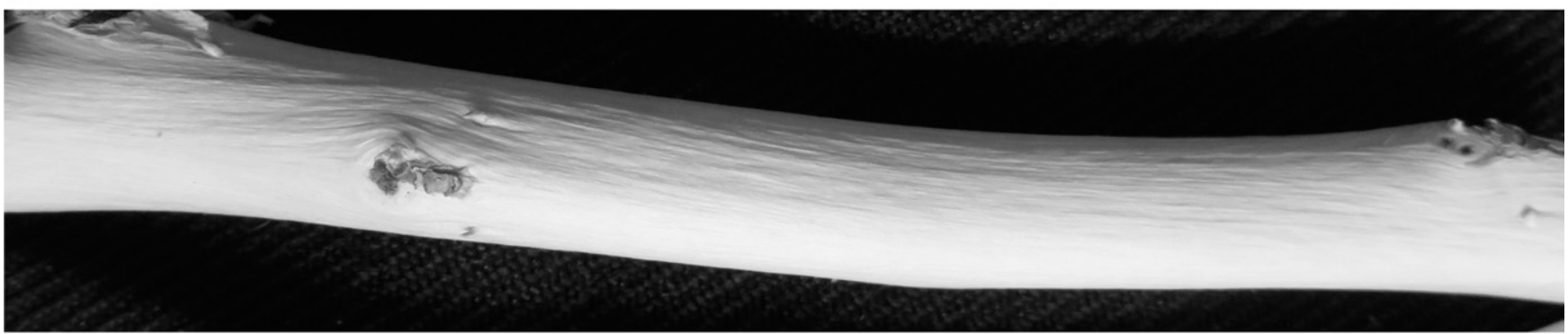

B

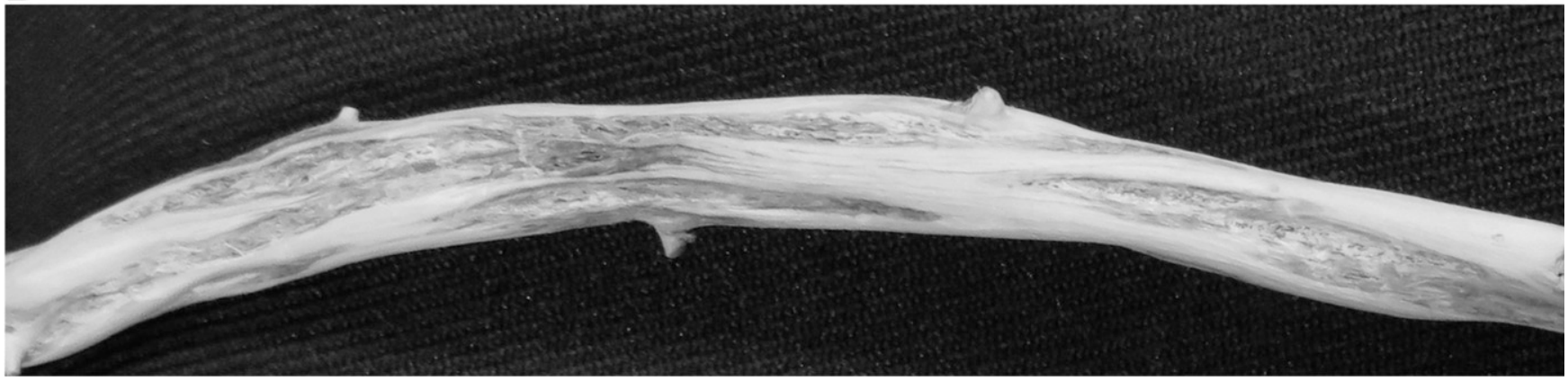

Fig. 1. GFMS12 propagation sources showing the absence and presence of stem pitting. A, Original GFMS12 source in Nartia grapefruit; and B, isolate GFMS12 in Duncan grapefruit showing severe stem pitting. 
PCR amplifications were performed using KAPA HiFi HotStart ReadyMix (KAPA Biosystems, Wilmington, MA) as per the supplier's protocol with $0.4 \mu \mathrm{M}$ of each primer in $25-\mu 1$ reactions. PCR products were gel-purified using the Zymoclean Gel DNA recovery kit (Zymo Research Corporation, Irvine, CA) and bidirectionally sequenced at Inqaba Biotech (Pretoria, South Africa). To generate complete genomes, low-quality bases were removed and the overlapping sequences were aligned using BioEdit (Hall 1999). The primers used for T68 isolate amplifications are provided in Supplementary Table S1.

Genome sequences of isolates GFMS12-8 and GFMS12-1.3 were verified by high-throughput sequencing (HTS). Total RNA was extracted from petioles, leaf midribs, and green bark scrapings using an adapted CTAB method (Ruiz-García et al. 2019) and shipped in $3 \times 100 \%$ ethanol and $0.1 \times 3 \mathrm{M}$ sodium acetate $(\mathrm{pH} 5.2)$ to Macrogen (Seoul, South Korea). The RNA quality was assessed using an Agilent 2100 Bioanalyzer (Agilent Technologies, Santa Clara, CA). A ribosome-depleted RNA library was prepared using the TruSeq Stranded Total RNA LT Plant Sample Prep Kit (Illumina, San Diego, CA) according to the manufacturer's instructions and sequenced on the Illumina NovaSeq, generating 100-bp paired-end reads. HTS reads were mapped to the T68 reference sequence (JQ965169) in CLC genomics Workbench 11.0.1 (CLCbio, Qiagen, Hilden, Germany) to extend the extreme $5^{\prime}$ and $3^{\prime}$ ends of the Sangergenerated genomes. Mapping to a reference sequence, for each of the eight genotypes, was also used to determine if different CTV genotypes or variants are present in each of the samples. Reads with more than one match were ignored, and the similarity fraction was increased to $95 \%$ over at least $90 \%$ of the read. A threshold of 10,000 reads, mapped across more than $95 \%$ of the genome, was regarded as the minimum requirement indicating the presence of a variant (Ruiz-García et al. 2019). HTS reads were mapped to the extended Sanger-generated genomes for GFMS12-8 and GFMS12-1.3 using default parameters. A consensus sequence was extracted from the alignment, and conflicts were resolved using vote resolution. Ambiguities were identified using the basic variant detection tool in CLC genomics Workbench 11.0.1 with minimum coverage of 1000 , minimum count of 500 and minimum frequency of $10 \%$.

HTS reads for samples GMFS12-8 and GMFS12-1.3 were also de novo assembled using default parameters in CLC genomics Workbench 10.1.1. Assembled contigs were identified using BLASTn (Altschul et al. 1990) to identify other viruses and viroids in the sample. Further sequence alignments and translations were performed in CLC Sequence Viewer 7.6.

Diagnostic differentiation of T68 variants. Primers were designed to amplify a 377-bp region encompassing five nucleotide polymorphisms identified within the ORF p33 of the GFMS12 T68 genomes as determined above. PCR amplicons were Sanger sequenced to identify the dominant variants in the GFMS12 source plants and to confirm transmission of isolates inoculated to Duncan grapefruit. Reverse transcription reactions were random primed as described above, and PCR was performed using $0.5 \mu \mathrm{M}$ of each primer (T68_J+ [5'-GATGTTGGTTATAATGCTGCCGA-3'] and T68_p33R1 [5'-ATTTTCGGATATCGTTTGTGTGC-3']) using Q5 Hot Start High Fidelity Master Mix (New England Biolabs, Ipswich, MA) in 20- $\mu 1$ reaction volumes. Cycling conditions included $98^{\circ} \mathrm{C}$ for $30 \mathrm{~s}$ followed by 35 cycles of $98^{\circ} \mathrm{C}$ for $5 \mathrm{~s}, 60^{\circ} \mathrm{C}$ for $30 \mathrm{~s}$, $72^{\circ} \mathrm{C}$ for $30 \mathrm{~s}$, and a final extension of $72^{\circ} \mathrm{C}$ for $5 \mathrm{~min}$. Amplicons were gel extracted using the Zymoclean Gel DNA recovery kit. Direct Sanger sequencing was performed at Inqaba Biotech using the forward primer.

\section{Results}

Genotype determination of GFMS12 propagation sources and isolates. Only the T68 genotype was detected in the original source plant of GFMS12 by testing six samples of the plant with genotype-specific RT-PCRs. Similarly, only the T68 genotype was detected in the Duncan grapefruit propagation source of GFMS12, maintained at CRI, and in isolates GFMS12-8 and GFMS12-1.3.

Biological evaluation of GFMS12-1.3 and GFMS12-8. Both T68 isolates, GFMS12-1.3 and GFMS12-8, were rated as mild strains according to the Garnsey disease index because they are both nondecline isolates that do not induce seedling yellows on either sour orange or Duncan grapefruit, nor do they induce stem pitting on sweet orange (Table 1). The sweet orange stem pitting phenotype is regarded as more severe than the grapefruit stem pitting phenotype and is weighted accordingly in the disease index. However, isolate GFMS12-1.3 induced severe stem pitting on Duncan grapefruit, compared with isolate GFMS12-8, which induced mild stem pitting. The Garnsey disease index therefore underrepresents the significance of stem pitting on grapefruit.

Stem pitting evaluation of isolates GFMS12-8 and GFMS12-1.3 on Duncan grapefruit in two separate trials consistently showed severe stem pitting associated with isolate GFMS12-1.3 and only mild to moderate stem pitting associated with isolate GFMS12-8. Figure 2 shows the stem pitting observed in the two separate trials. Differences in stem pitting severity were observed in the first evaluation of trial 1 plants after 4 months of growth. However, the distinction in symptom expression between the isolates became more prominent after longer growth periods. Severe, porous stem pitting associated with isolate GFMS12-1.3 was observed in trials 1 and 2 after growth periods of 12 and 9 months, respectively.

Sequence comparison of isolates GFMS12-8 and GFMS12-1.3. HTS analysis confirmed the presence of only the T68 genotype in both the GFMS12-8 and GFMS12-1.3 samples. No other viruses and viroids were identified. Mapping of more than 1.4 million and 2.1 million reads for the GFMS12-8 and GFMS12-1.3 samples, respectively, across $98 \%$ of the T68 reference sequence was indicative of the presence of this genotype. The closest other genotype showed read mapping to only 83 and $40 \%$ of the genome for the GFMS12-8 and GFMS12-1.3 samples, respectively. These read mapping percentages are consistent with sequence similarities between genotypes and do not indicate the presence of another genotype.

Complete genome nucleotide sequences for isolates GFMS12-1.3 and GFMS12-8 were obtained with Sanger sequencing and validated independently by HTS. Eleven out of the 14 nucleotide degeneracies that were found in the HTS data of GFMS12-1.3 and GFMS12-8 were also identified in the Sanger sequence data (Supplementary Table S2). When Sanger sequencing indicated a single nucleotide, the most prevalent nucleotide found with HTS at that position agreed with the Sanger nucleotide call. The genome positions and nucleotide degeneracies are tabulated in Supplementary Table S2. Consensus

Table 1. Virulence indexing of single-genotype citrus tristeza virus (CTV) isolates GFMS12-8 and GFMS12-1.3 based on the Garnsey host range disease index (DI) per host and cumulative disease index score $\left(\sum \mathrm{DI}\right)$

\begin{tabular}{llcccccc}
\hline & & \multicolumn{5}{c}{ Average DI per citrus host ${ }^{\mathbf{a}}$} \\
\cline { 3 - 7 } CTV isolate & Strain & ML $(\times \mathbf{1})$ & SW/SO $(\times \mathbf{2})$ & SO $(\times \mathbf{3})$ & DGF $(\times \mathbf{4})$ & MV $(\times \mathbf{5})$ & $\sum$ DI \\
\hline Uninoculated control & $\ldots$ & 0 & 0 & 0 & 0 & 0 \\
GFMS12-8 & T68 & 1.9 & 0 & 0 & 1.3 & 0 \\
GFMS12-1.3 & T68 & 2.3 & 0 & 0 & 4.6 & 0 & 6.2 \\
\hline
\end{tabular}

${ }^{a}$ Individual symptoms were rated as $0=$ no symptoms, $1=$ mild, $2=$ moderate, and $3=$ severe. The component scores for individual symptoms for each host were averaged and the composite score multiplied by the weight factor for each host as indicated. Symptoms scored per host were as follows: ML = Mexican lime, vein clearing and stem pitting $(\mathrm{SP}) ; \mathrm{SW} / \mathrm{SO}=$ sweet orange/sour orange, stunting/decline; $\mathrm{SO}=$ sour orange, seedling yellows $(\mathrm{SY})$ and stunting; DGF = Duncan grapefruit, SY, SP, and stunting; and MV = Madam Vinous, SP and stunting. 
sequences using both Sanger and HTS data were generated and deposited in GenBank under the accession numbers MK033510 and MK033511 for GFMS12-1.3 and GFMS12-8, respectively.

Isolates GFMS12-1.3 (MK033510) and GFMS12-8 (MK033511)

both share $97.4 \%$ nucleotide identity with the type member of the T68 genotype, T68-1 (JQ965169) (Harper 2013).

GFMS12-8 (MK033511) shares 99.9\% identity with CT-ZA3 (KC333868), which is a propagation of the GFMS12-8 source
(Zablocki and Pietersen 2014). GFMS12-8 and CT-ZA3 both share 99.8\% with GFMS12-1.3 (MK033510).

The genomes of CTV isolates GFMS12-8 and GFMS12-1.3 were compared, and 45 nucleotide polymorphisms were identified over the length of the genome (Supplementary Table S3). These are indicated as either synonymous or nonsynonymous differences in Figure 3. The most changes were detected in the LPro domains of ORF1a and in the ORF of p33. Six of the nucleotide polymorphisms between

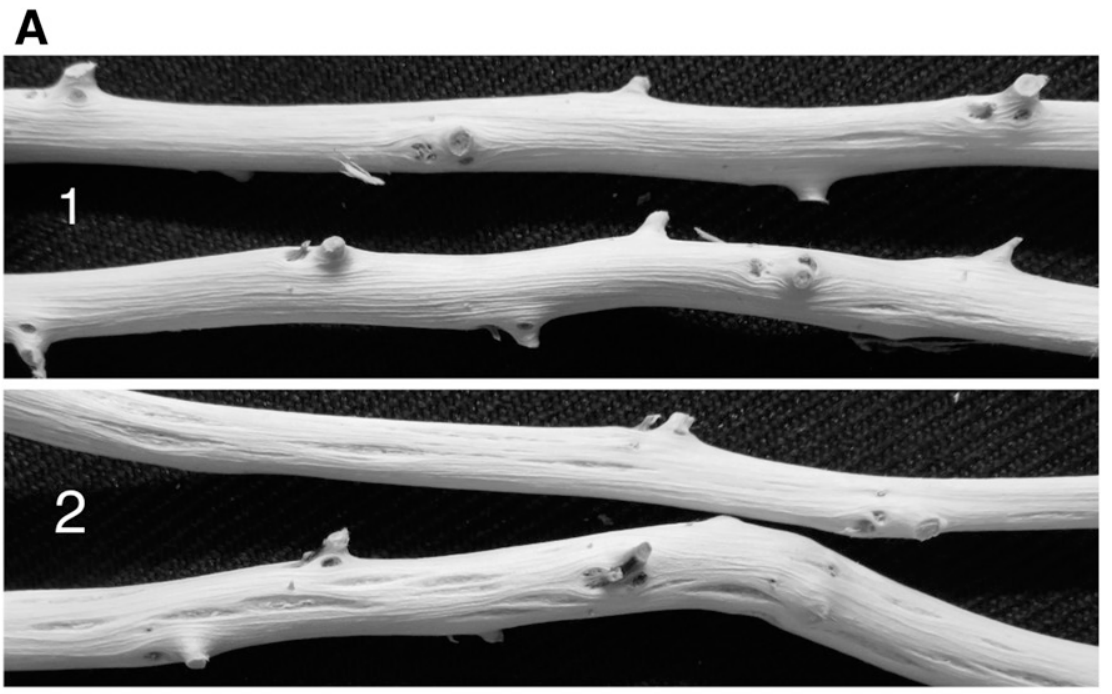

B

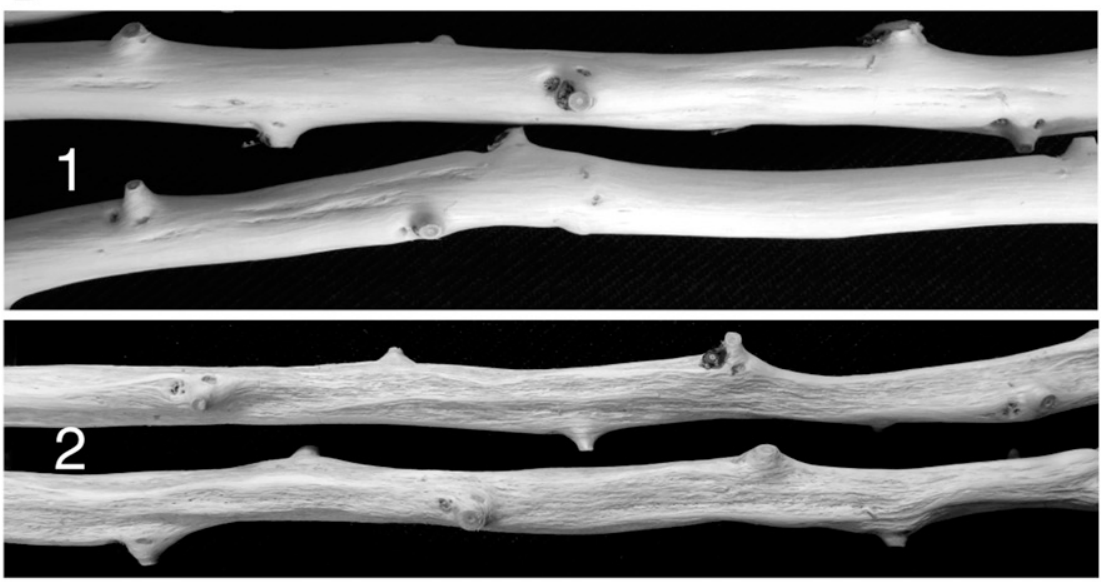

C
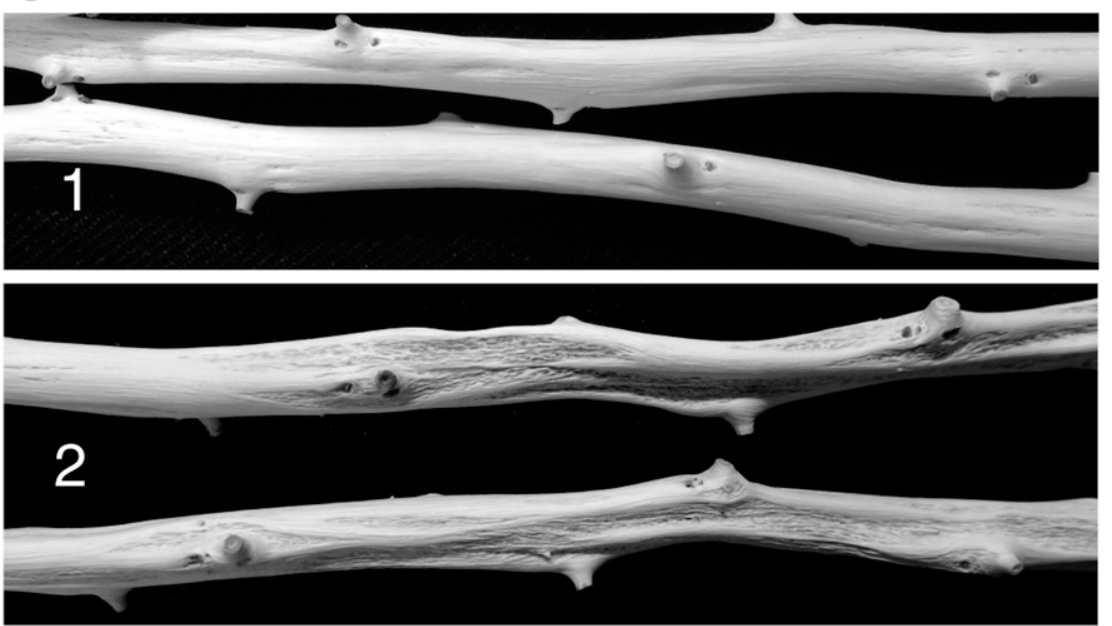

Fig. 2. Stem pitting on Duncan grapefruit obtained with T68 isolates GFMS12-8 (1) and GFMS12-1.3 (2) in two separate trials. A, Trial 1, stems cut back 4 months postinoculation; B, trial 1, stems cut back after a further 12 months of growth; and C, trial 2, stems cut back 9 months postinoculation. 
GFMS12-8 and GFMS12-1.3 were also identified as ambiguous bases in the HTS data, five in GFMS12-8 and one in GFMS12-1.3 (Supplementary Table S3). One of these nucleotide polymorphisms in ORF1a of GFMS12-8 changes the classification of the amino acid from hydrophobic (Ala) to hydrophilic (Thr), which can influence protein function.

Nucleotide polymorphisms in the p33 ORF. The five nonsynonymous polymorphisms in the $\mathrm{p} 33 \mathrm{ORF}$, located within a short genome segment, were used to discriminate the T68 isolates. Graft transmissions of isolates GFMS12-1.3 and GFMS12-8 to Duncan grapefruit were confirmed by RT-PCR amplification of this region and amplicon sequencing. The five distinguishing nucleotides were consistently detected in the respective inoculated plants, indicating that these nucleotide differences were stably maintained.

The p33 diagnostic region was also amplified and sequenced for the two GFMS12 source plants: the original source at ARC-TSC and the propagation source in Duncan grapefruit at CRI. The CRI GFMS12 propagation source, displaying severe stem pitting, had the sequence identical to isolate GFMS12-1.3, which was derived from this source, indicating that GFMS12-1.3 was most likely the dominant T68 variant in the CRI GFMS12 propagation source plant. The original ARC-TSC GFMS12 source plant is a larger plant, and for that reason, six separate branches were sampled in order to detect possible sectorial differences in the plant. The same sequence was obtained for the six samples. The consensus sequence, as shown in the alignment of Figure 4, differed from both that of GFMS12-1.3 and GFMS12-8. Three of the five distinctive nucleotide positions were the same as for GFMS12-1.3, whereas the nucleotides at the other two positions were the same as for GFMS12-8.

\section{Discussion}

Characterization of CTV isolates was previously reliant on the isolation and biological evaluation of components of CTV populations.
The ability to identify strains and confirm single-genotype CTV sources with current diagnostic capabilities enables the linkage of biological expression to specific genomes.

We identified a CTV T68 genotype as the only component of the original GFMS12 population. T68 isolates, GFMS12-1.3 and GFMS12-8, were derived at different time points from the original GFMS12 source through propagation to various host plants and isolation by aphid transmission. Two of the resulting isolates displayed differential stem pitting phenotypes in grapefruit shown in Figure 2 and reflected in the Garnsey biological evaluation (Table 1). We speculate that the various inoculation and transmission events to new host plants created genetic bottlenecks that resulted in the segregation of T68 variants from the original quasispecies population. It is uncertain, in the absence of experimental data, if this segregation was due to selection or just random change. Change in pathogenicity was especially evident with the inoculation of the GFMS12 source from the original Nartia to Duncan grapefruit, which resulted in a phenotypic change from mild to severe stem pitting (Fig. 1), from which isolate GFMS12-1.3 was derived. The T68 isolate, GFMS12-8, was obtained by transfer from the original population to Mexican lime, a new host species, and subsequent aphid transmission (van Vuuren et al. 2000). The phenomenon that a host change can alter virus population structures was previously demonstrated for CTV (Černi et al. 2008). However, the original GFMS12 source plant displayed low genetic diversity, with only a single genotype, T68, and therefore the segregation of genetic variants from the source plant was achieved from the quasispecies population.

Full-genome analysis showed that the symptomatically diverse isolates, GFMS12-1.3 and GFMS12-8, differed at only 45 nucleotide positions, of which 24 were nonsynonymous substitutions (Fig. 3). Thirteen of these nonsynonymous substitutions changed the classification of the amino acid (Supplementary Table S3). Minor nucleotide changes resulting in significant phenotypic changes are documented

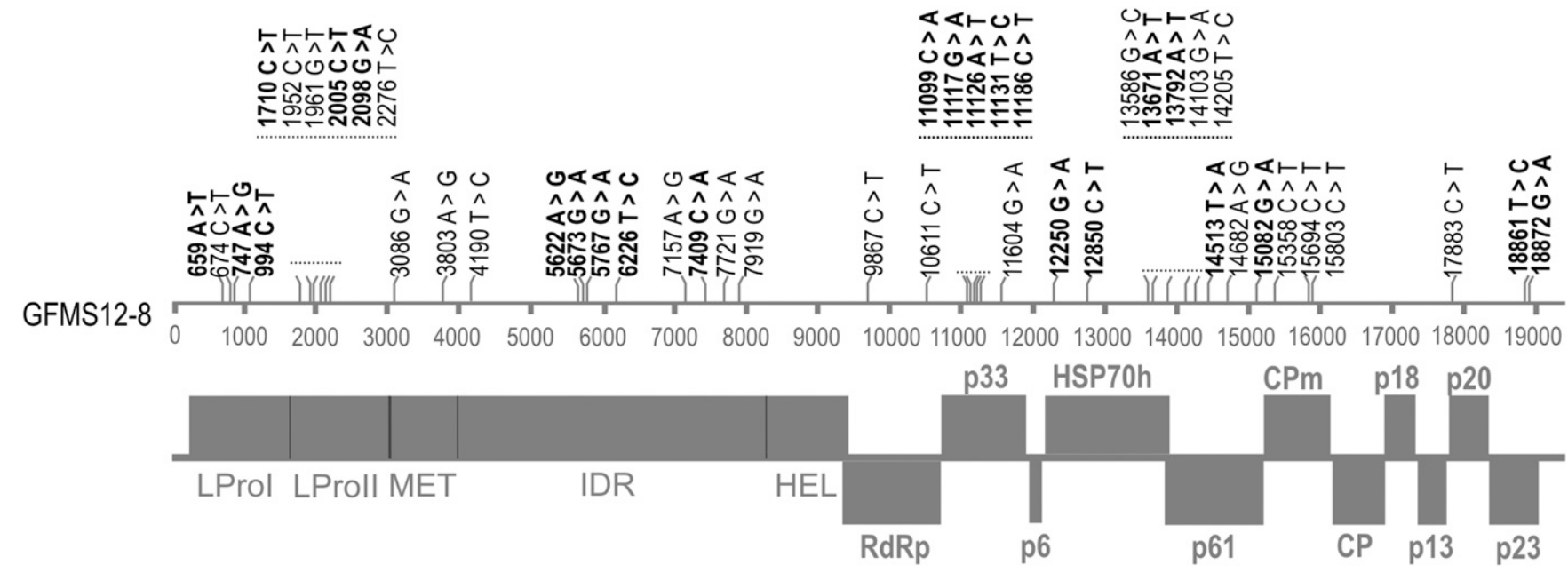

Fig. 3. Nucleotide polymorphisms between genomes of isolates GFMS12-8 and GFMS12-1.3. Nucleotide differences and positions are indicated on the GFMS12-8 genome. Nonsynonymous substitutions are indicated in bold. Boxes show the relative positioning of the open reading frames.

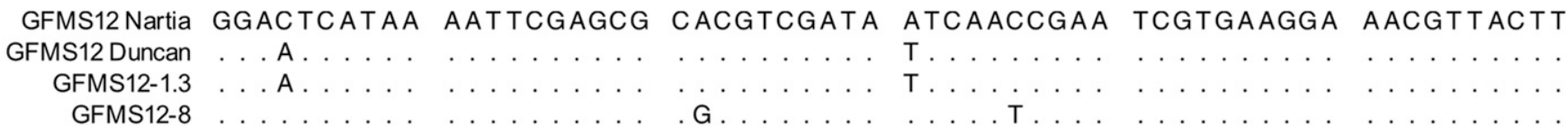

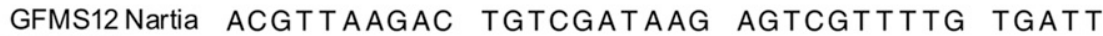

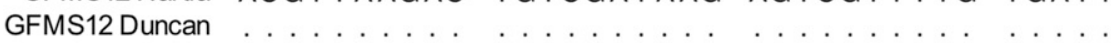

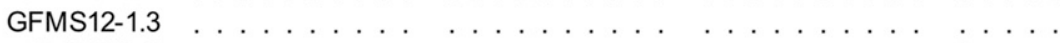

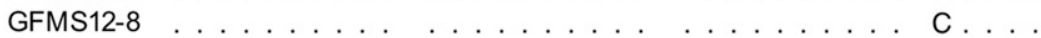

Fig. 4. Nucleotide sequence alignment of the p33 diagnostic region for T68 variant discrimination including the dominant variant sequences in two GFMS12 propagation plants and sequences of isolates GFMS12-1.3 and GFMS12-8. Dots indicate equivalent nucleotides. 
for viruses of annual crops (Koh et al. 2017; Lin et al. 2007; Weber et al. 1993), but evidence is limited for CTV (Harper et al. 2016; Scuderi et al. 2017).

We demonstrate in this study that different T68 variants dominate in different propagation sources of GFMS12. A population of quasispecies are known to develop with viruses that replicate with high error rates (Holmes 2009; Sanjuán and Domingo-Calap 2016). Viruses consequently develop heterogeneity over time, and variants are found that oscillate around a master sequence in a host (GarcíaArenal et al. 2001). The formation of these variants has biological significance as a mechanism for viral adaption to new hosts and environmental conditions. Through various graft inoculations (sometimes to a different citrus species) and aphid transmissions, several genetic bottlenecks were created that drove the divergence of the genetic variants in this study. A higher number of ambiguous bases were observed in isolate GFMS12-8 (1996) compared with isolate GFMS12-1.3 (2016), which was isolated and characterized 20 years later (Supplementary Table S2). It can be inferred that a longer infection period will allow for greater variation to develop in a quasispecies population due to the error-prone replication of the RNA-dependent RNA polymerase (Holmes 2009; Sanjuán and Domingo-Calap 2016).

Pathogenicity determinants for stem pitting have not been defined for CTV. However, ORFs p13, p18, and p33 were implicated and potentially influence stem pitting by interactive gene expression (Tatineni and Dawson 2012). It is therefore noteworthy that five nonsynonymous nucleotide changes between the two isolates were found in ORF p33 that may be responsible for the different stem pitting phenotypes. Apart from this genome region, nucleotide changes were found in clusters in ORF1a in both the LProI and LProII domains. Leader proteases of closteroviruses are involved in virus infection and cell-to-cell movement and can therefore also potentially play a role in pathogenicity (Liu et al. 2009; Peng et al. 2001). Clusters of nucleotide changes observed in certain genome domains will therefore be targets for further investigations as possible stem pitting determinants.

This study demonstrates the existence of mild and severe strains of a single genotype, suggesting that host and aphid transfers can effect a change in the quasispecies population to create new populations with a changed dominant variant. Naturally occurring mild and severe stem pitting strains of the same genotype lends credence to the superinfection exclusion principle as a mechanism explaining cross-protection. Using an infectious T36 clone it was demonstrated that infection with the clone was not possible if the plant contained a primary infection of a natural T36 isolate, but this exclusion did not occur with heterologous strains (Folimonova et al. 2010). At the time that the mechanism was proposed, the existence of biologically different strains of a genotype was not yet demonstrated as we do in this study. Cross-protection studies with naturally occurring variants can now be conducted to test the principle.

\section{Acknowledgments}

The authors acknowledge Dr. S. P. van Vuuren for his foundational work on CTV and for the foresight to maintain the isolates of GFMS12.

\section{Literature Cited}

Altschul, S. F., Gish, W., Miller, W., Myers, E. W., and Lipman, D. J. 1990. Basic local alignment search tool. J. Mol. Biol. 215:403-410.

Bar-Joseph, M., Marcus, R., and Lee, R. F. 1989. The continuous challenge of citrus tristeza virus control. Annu. Rev. Phytopathol. 27:291-316.

Broadbent, P., Indsto, J., Dephoff, C., and Owen-Turner, J. 1992. An outbreak of orange stem pitting in Queensland, Australia. Pages 769-771 in: Proceedings of the International Society of Citriculture.

Černi, S., Ruščić, J., Nolasco, G., Gatin, Ž., Krajačić, M., and Škorić, D. 2008. Stem pitting and seedling yellows symptoms of citrus tristeza virus infection may be determined by minor sequence variants. Virus Genes 36:241-249.

Cook, G., van Vuuren, S. P., Breytenbach, J. H. J., Burger, J. T., and Maree, H. J. 2016. Expanded strain-specific RT-PCR assay for differential detection of currently known citrus tristeza virus strains: A useful screening tool. J. Phytopathol. 164:847-851.

da Graca, J. V., and van Vuuren, S. P. 2010. Managing citrus tristeza virus losses using cross protection. Pages 247-260 in: Citrus Tristeza Virus Complex and
Tristeza Diseases. A. V. Karasev and M. E. Hilf, eds. American Phytopathological Society, St. Paul, MN.

Folimonova, S. Y., Robertson, C. J., Shilts, T., Folimonov, A. S., Hilf, M. E., Garnsey, S. M., and Dawson, W. O. 2010. Infection with strains of citrus tristeza virus does not exclude superinfection by other strains of the virus. J. Virol. 84:1314-1325.

García-Arenal, F., Fraile, A., and Malpica, J. M. 2001. Variability and genetic structure of plant virus populations. Annu. Rev. Phytopathol. 39:157-186.

Garnsey, S. M., Gumpf, D. J., Roistacher, C. N., Civerolo, E. L., Lee, R. F., Yokomi, R. K., and Bar-Joseph, M. 1987. Toward a standardized evaluation of the biological properties of citrus tristeza virus. Pytophylactica 19:151-158.

Hall, T. A. 1999. BioEdit: A User-friendly biological sequence alignment editor and analysis program for Windows 95/98/NT. Nucleic Acids Symp. Ser. 41: 95-98.

Harper, S. J. 2013. Citrus tristeza virus: Evolution of complex and varied genotypic groups. Front. Microbiol. 4:93.

Harper, S. J., Killiny, N., Tatineni, S., Gowda, S., Cowell, S. J., Shilts, T., and Dawson, W. O. 2016. Sequence variation in two genes determines the efficacy of transmission of citrus tristeza virus by the brown citrus aphid. Arch. Virol. 161:3555-3559.

Holmes, E. C. 2009. The evolutionary genetics of emerging viruses. Annu. Rev. Ecol. Evol. Syst. 40:353-372.

Hughes, W. A., and Lister, C. A. 1949. Lime disease in the Gold Coast. Nature 164:880.

Karasev, A. V., Boyko, V. P., Gowda, S., Nikolaeva, O. V., Hilf, M. E., Koonin, E. V., Niblett, C. L., Cline, K., Gumpf, D. J., Lee, R. F., Garnsey, S. M., Lewandowski, D. J., and Dawson, W. O. 1995. Complete sequence of the citrus tristeza virus RNA genome. Virology 208:511-520.

Koh, S. H., Li, H., Sivasithamparam, K., Admiraal, R., Jones, M. G. K., and Wylie, S. J. 2017. Evolution of a wild-plant tobamovirus passaged through an exotic host: Fixation of mutations and increased replication. Virus Evol. 3:vex001.

Lin, S.-S., Wu, H.-W., Jan, F.-J., Hou, R. F., and Yeh, S.-D. 2007. Modifications of the helper component-protease of zucchini yellow mosaic virus for generation of attenuated mutants for cross protection against severe infection. Phytopathology 97:287-296.

Liu, Y.-P., Peremyslov, V. V., Medina, V., and Dolja, V. V. 2009. Tandem leader proteases of grapevine leafroll-associated virus-2: Host-specific functions in the infection cycle. Virology 383:291-299.

Marais, L. J. 1994. Citrus tristeza virus and its effect on the southern Africa citrus industry. Citrus Ind. 75:58-60.

Martelli, G. P., Abou Ghanem-Sabanadzovic, N., Agranovsky, A. A., Al Rwahnih, M., Dolja, V. V., Dovas, C. I., Fuchs, M., Gugerli, P., Hu, J. S., Jelkmann, W. Katis, N. I., Maliogka, V. I., Melzer, M. J., Menzel, W., Minafra, A., Rott, M. E., Rowhani, A., Sabanadzovic, S., and Saldarelli, P. 2012. Taxonomic revision of the family Closteroviridae with special reference to the grapevine leafroll-associated members of the genus Ampelovirus and the putative species unassigned to the family. J. Plant Pathol. 94:7-19.

Moreno, P., Ambros, S., Albiach-Marti, M. R., Guerri, J., and Peña, E. 2008. Citrus tristeza virus: A pathogen that changed the course of the citrus industry. Mol Plant Pathol. 9:251-268.

Muller, G. W. 1980. Use of mild strains of citrus tristeza virus (CTV) to reestablish commercial production of 'Pera' sweet orange in Sao Paulo, Brazil. Proc. Fla. State Hortic. Soc. 93:62-64.

Muller, G. W., and Costa, A. S. 1987. Search for outstanding plants in tristeza infected citrus orchards: The best approach to control the disease by preimmunization. Phytophylactica 19:197-198.

Müller, G. W., Rodriguez, O., and Costa, A. S. 1968. A tristeza virus complex severe to sweet orange varieties. Pages 64-71 in: Proc.4th Conf. Int. Organ. Citrus Virol., J. F. L. Childs, ed. University of Florida Press, Gainesville, FL.

Peng, C.-W., Peremyslov, V. V., Mushegian, A. R., Dawson, W. O., and Dolja, V. V. 2001. Functional specialization and evolution of leader proteinases in the family Closteroviridae. J. Virol. 75:12153-12160.

Roistacher, C. N., and Dodds, J. A. 1993. Failure of 100 mild citrus tristeza virus isolates from California to cross protect against a challenge by severe sweet orange stem pitting isolates. Pages 100-107 in: Proc. 12th Conf. Int. Organ. Citrus Virol. P. Moreno, J. V. da Graca, and L. W. Timmer, eds. IOCV, Riverside, CA.

Roistacher, C. N., Dodds, J. A., and Bash, J. A. 1987. Means of obtaining and testing protective strains of seedling yellows and stem pitting tristeza virus: A preliminary report. Phytophylactica 19:199-203.

Roistacher, C. N., Dodds, J. A., and Bash, J. A. 1988. Cross protection against citrus tristeza seedling yellows and stem pitting virus by protective isolates developed in greenhouse plants. Pages 91-100 in: Proc.10th Conf. Int. Organ. Citrus Virol. L. W. Timmer, S. M. Garnsey, and L. Navarro, eds. IOCV, Riverside, CA

Ruiz-García, A. B., Bester, R., Olmos, A., and Maree, H. J. 2019. Bioinformatic tools and genome analysis of citrus tristeza virus. Pages 163-178 in: Citrus Tristeza Virus: Methods and Protocols. A. F. Catara, M. Bar-Joseph, and G. Licciardello, eds. Springer, New York, NY.

Sanjuán, R., and Domingo-Calap, P. 2016. Mechanisms of viral mutation. Cell. Mol. Life Sci. 73:4433-4448.

Sasaki, A., Tsuchizaki, T., and Saito, Y. 1980. Distribution of citrus tristeza virus antigen in citrus tissues. Pages 17-19 in: Proc. 8th Conf. Int. Organ. Citrus 
Virol. E. C. Calavan, S. M. Garnsey, and L. W. Timmer, eds. IOCV, Riverside CA.

Scuderi, G., Ferraro, R., Russo, M., Bazzano, M. C., Catara, A., and Licciardello, G. 2017. Selection of genetic variants of citrus tristeza virus as a strategy to protect against severe seedling yellows strains. [Abstr.] Phytopathol. Mediterr. 56:278-378.

Tatineni, S., and Dawson, W. O. 2012. Enhancement or attenuation of disease by deletion of genes from citrus tristeza virus. J. Virol. 86:7850-7857.

van Vuuren, S. P., Collins, R. P., and da Graca, J. V. 1991. The performance of exotic citrus tristeza virus isolates as pre-immunizing agents for sweet orange on sour orange rootstock under natural disease pressure in South Africa. Pages 60-63 in: Proc. 11th Conf. Int. Organ. Citrus Virol. R. H. Brlansky, R. F. Lee, and L. W. Timmer, eds. IOCV, Riverside CA.

van Vuuren, S. P., and da Graca, J. V. 2000. Reduction in 'Marsh' grapefruit tree size infected with citrus tristeza virus populations. J. Hortic. Sci. Biotechnol. 75:542-545.

van Vuuren, S. P., and Manicom, B. Q. 2005. The response of Star Ruby grapefruit to different citrus tristeza virus isolates. Pages 112-116 in: Proc. 16th Conf. Int.
Organ. Citrus Virol. M. E. Hilf, N. Duran Vila, and M. A. Rocha-Peña, eds. IOCV, Riverside CA.

van Vuuren, S. P., van der Vyver, J. B., and Luttig, M. 2000. Diversity among subisolates of cross-protecting citrus tristeza virus isolates in South Africa. Pages 103-110 in: Proc. 14th Conf. Int. Organ. Citrus Virol. J. V. da Graca, R. F. Lee, and R. K. Yokomi, eds. IOCV, Riverside CA.

Weber, H., Schultze, S., and Pfitzner, A. J. 1993. Two amino acid substitutions in the tomato mosaic virus 30-kilodalton movement protein confer the ability to overcome the Tm-2(2) resistance gene in the tomato. J. Virol. 67:6432-6438.

Yokomi, R., Selvaraj, V., Maheshwari, Y., Chiumenti, M., Saponari, M. Giampetruzzi, A., Weng, Z., Xiong, Z., and Hajeri, S. 2018. Molecular and biological characterization of a novel mild strain of citrus tristeza virus in California. Arch. Virol. 163:1795-1804.

Zablocki, O., and Pietersen, G. 2014. Characterization of a novel citrus tristeza virus genotype within three cross-protecting source GFMS12 sub-isolates in South Africa by means of Illumina sequencing. Arch. Virol. 159:21332139. 